\title{
Leased Office Space for the Yucca Mountain Project
}

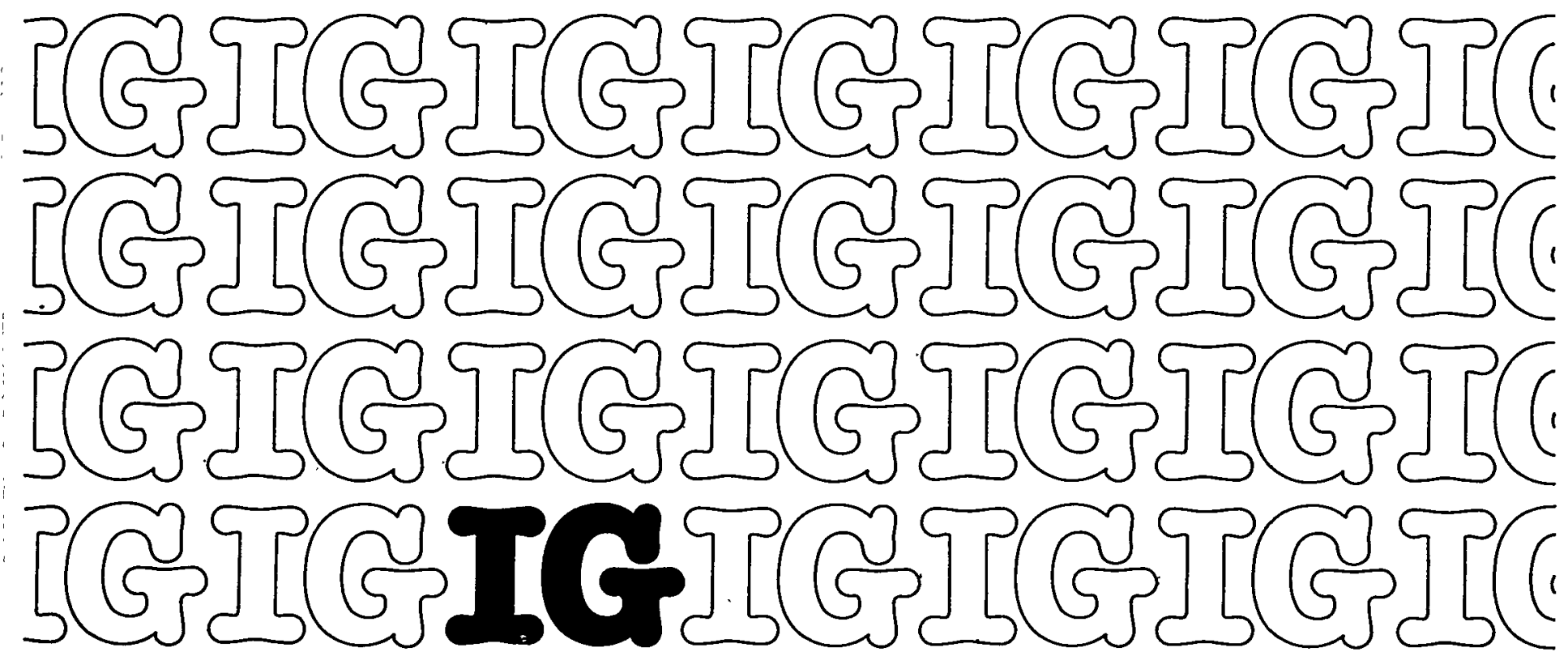


The Honorable John C. Layton

Inspector General

U.S. Department of Energy

1000 Independence Ave., S.W.

Washington, D.C. 20585

Dear Mr. Layton:

I have reviewed your report entitled "Leased office Space for the Yucca Mountain Project." As a result, today I am tasking the Director, Office of Civilian Radioactive Waste Management to report to me with recommendations for corrective actions within 90 days. I will take appropriate actions promptly.

Thank you for your continuing efforts to ensure the Department's accountability.

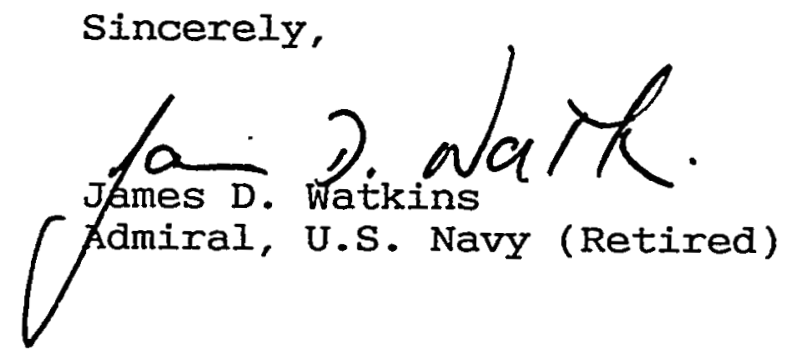


DATE: September 5, 1990

REPLY TO ATTN OF:

SUBJECT:

TO:
IG-1

INFORMATION: Report on "Leased Office Space for the Yucca Mountain Project"

\section{The secretary}

\section{BACKGROUND:}

The attached report is being sent to you to inform you of our findings and recommendations and to provide you with an opportunity to comment.

The audit objective was to assess the Department of Energy Yucca Mountain Project Office's (Project Office) oversight of the Yucca Mountain Project contractor's leasing of office space.

\section{DISCUSSION :}

The Project Office, a part of the Department's Office of Civilian Radioactive Waste Management (OCRWM), has overall responsibility for managing the Yucca Mountain Project with a Fiscal Year (FY) 1990 budget of $\$ 172.5$ million. In 1989 , the Project Office requested Science Applications International Corporation (SAIC), a support service contractor, to extend a lease for 191,000 square feet of office space to centrally locate all project participants and their 700 employees.

Department policy required contractors to comply with the General Services Administration's (GSA) office space standard and to limit Department liability before leasing. SAIC's leased office space exceeded the GSA space standard by about 45,000 square feet and did not include a contract clause to limit future lease liabilities. Project office officials mistakenly believed that Department policy was not applicable when a contractor, such as SAIC, signs the lease. By exceeding the GSA space standard and not limiting Departmental liability, SAIC incurred unreasonable costs of approximately $\$ 600,000$ and could incur an additional $\$ 1.2$ million if existing space arrangements are not reduced. Furthermore, the Department could be liable for any remaining portion of the first 12 months of the lease should the project be reduced or terminated.

OCRWM officials agreed with our findings and recommendations. However, OCRWM officials advised that reducing space to GSA standards would require reconfiguration costing as much as $\$ 2.4$ million. OCRWM officials believed that any savings from releasing excess space may be negated by reconfiguration costs. 
We agreed that reconfiguration may be necessary to reduce space to the GSA standard and that the cost of reconfiguration could negate the savings associated with releasing the excess space. Nevertheless, since SAIC has 2 years remaining on the current option and another option for 4 years, the project will ultimately achieve savings of at least $\$ 1.2$ milizon after the reconfiguration costs have been recovered.

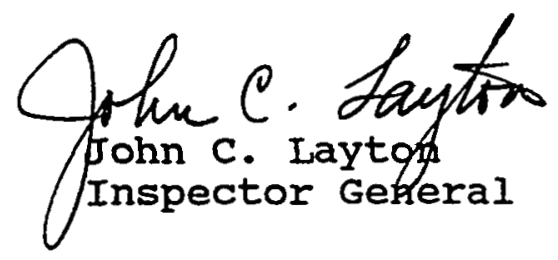

Attachment

cc: Under Secretary

Director, Office of Civilian Radioactive Waste Management Manager, Nevada Operations office

Manager, Yucca Mountain Project office

Director, Audit Liaison Staff, MA-31.2 


\section{DISCLAIMER}

This report was prepared as an account of work sponsored by an agency of the United States Government. Neither the United States Government nor any agency thereof, nor any of their employees, make any warranty, express or implied, or assumes any legal liability or responsibility for the accuracy, completeness, or usefulness of any information, apparatus, product, or process disclosed, or represents that its use would not infringe privately owned rights. Reference herein to any specific commercial product, process, or service by trade name, trademark, manufacturer, or otherwise does not necessarily constitute or imply its endorsement, recommendation, or favoring by the United States Government or any agency thereof. The views and opinions of authors expressed herein do not necessarily state or reflect those of the United States Government or any agency thereof. 


\section{DISCLAIMER}

Portions of this document may be illegible in electronic image products. Images are produced from the best available original document. 
U. S. DEPARTMENT OF ENERGY

OFFICE OF INSPECTOR GENERAL

\section{LEASED OFFICE SPACE}

FOR THE YUCCA MOUNTAIN PROJECT

Report NO.: DOE/IG-0288

Date of Issue: September 5, 1990
Western Regional office Albuquerque, NM 87115 
Purpose and scope of Audit................... I

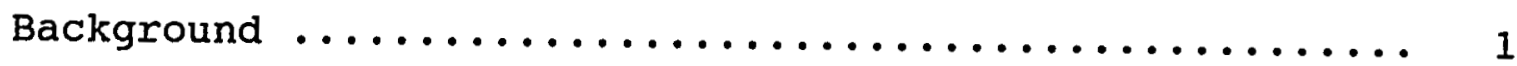

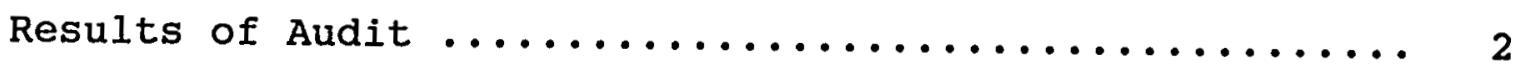

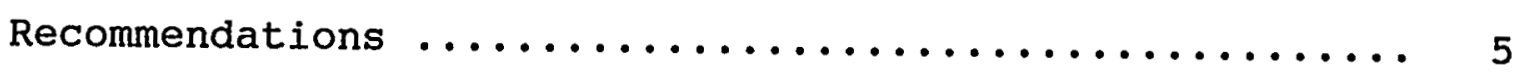

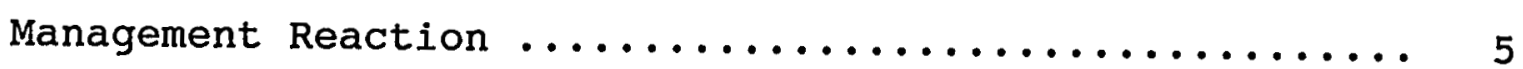

Auditor Comments $\ldots \ldots \ldots \ldots \ldots \ldots \ldots \ldots \ldots \ldots \ldots$ 
OFFICE OF INSPECTOR GENERAL

WESTERN REGIONAL OFFICE

ALBUQUERQUE, NEW MEXICO 87115

\section{LEASED OFFICE SPACE \\ FOR THE YUCCA MOUNTAIN PROJECT}

Report No.: DOE/IG-0288

PURPOSE AND SCOPE OF AUDIT

This audit assessed the Department of Energy Yucca Mountain Project Office's (Project Office) oversight of the Yucca Mountain Project contractor's leasing of office space.

To accomplish the audit objective, we interviewed Department of Energy's Nevada Operations Office, Yucca Mountain Project office, and contractor officials, and reviewed: (1) Department of Energy (Department) policies, procedures, and practices; (2) General Services Administration (GSA) requirements for utilization of Federally owned or leased space; and (3) the lease for the Valley Bank Complex, Las Vegas, Nevada. In addition, we analyzed space utilization as of February 1, 1990, for the Yucca Mountain Project and compared the results to the GSA standard.

Our examination followed generally accepted government auditing standards for performance audits, including tests of internal controls and compliance with applicable laws and regulations to the extent necessary to satisfy the audit objective. Since our review was limited, it would not necessarily have disclosed all material internal control weaknesses. However, our findings relating to the project Office's oversight of its contractor's leasing activity showed internal control weaknesses which should be considered when preparing the yearend assurance memorandum on internal controls.

We discussed our findings with the Associate Director, Office of Program Administration and Resources Management, Office of Civilian Radioactive Waste Management, during an exit conference on July 10, 1990. We have incorporated management comments into the body and in the Management Reaction sections of the report.

\section{BACKGROUND}

The Project Office, part of the Department's Office of Civilian Radioactive Waste Management (OCRWM), had the overall responsibility for managing the Yucca Mountain Project with a Fiscal Year (FY) 1990 budget of $\$ 172.5$ million. Since 1983, the Project office had contracted with science Applications International Corporation (SAIC), under a cost-reimbursable contract, to provide technical and management support services. 
In 1987, the Project office requested that SAIC acquire office space specifically for the Yucca Mountain Project sufficient to centrally locate all project participants. In response to this request, SAIC entered into a 3-year lease for 105,000 square feet with two options. The first option provided for a 3-year extension of the basic lease and the second option provided for another extension of 4 years.

The basic lease originally provided about 105,000 square feet of space, at a cost of $\$ 1.3$ million per year, in the Valley Bank Building, Las Vegas, Nevada, to house both Government and contractor employees assigned to the Yucca Mountain Project. Since 1987, SAIC increased the basic lease square footage so that as of February 1990 the amount of leased space had grown to approximately 191,000 square feet, at an annual cost of $\$ 2.5$ million. In anticipation of the March 3 , 1990 expiration date of the basic lease, SAIC exercised the first option on January 3, 1990, extending the basic lease for another 3 years at an annual cost of approximately $\$ 2.5$ million.

\section{RESULTS OF AUDIT}

Department policy required contractors to comply with the GSA office space standard and to limit Department liability before leasing. SAIC leased office space that exceeded the GSA space standard by about 45,000 square feet and did not include a contract clause to limit future lease liabilities. Project office officials mistakenly believed that Department policy was not applicable when a contractor, such as SAIC, signs the lease. By exceeding the GSA space standard and not limiting Departmental liability, SAIC incurred unreasonable costs of approximately $\$ 600,000$ and could incur an additional $\$ 1.2$ million if existing space arrangements are not reduced. Furthermore, the Department could be liable for any remaining portion of the first 12 months of the lease should the project be reduced or terminated.

\section{Department and GSA Requirements}

The Request for Proposal (RFP), under which the Department awarded SAIC its contract, stated that if office space were leased solely for the Yucca Mountain Project, the lease must conform to the requirements established in Department order 4300.1A. This order, dated July 7, 1983, and entitled "Real Estate (Real Property) Management," established how to handle contractor leased space. Specifically, the order required contractors to comply with GSA space standards. In addition, this order required a clause in each lease limiting the Department's liability in case of project termination. 
In its Temporary Regulation D-73, dated January 8, 1987, GSA clearly specified standards requiring all Federal agencies to meet an average space utilization of 135 square feet per staff member by the end of FY 1990. This regulation further allowed that an agency could justify up to 205 square feet which would include supplemental space, such as reception areas, conference rooms, file rooms, lounges, and other similar multi-purpose areas.

\section{SAIC's office space}

SAIC's leased space of 191,000 square feet exceeded the GSA space-per-person standard for office space by 45,000 square feet. As of February 1, 1990, except for REECo, the space allotted to the Yucca Mountain Project participants exceeded the GSA standard of 205 square feet per employee as shown in the graph below.

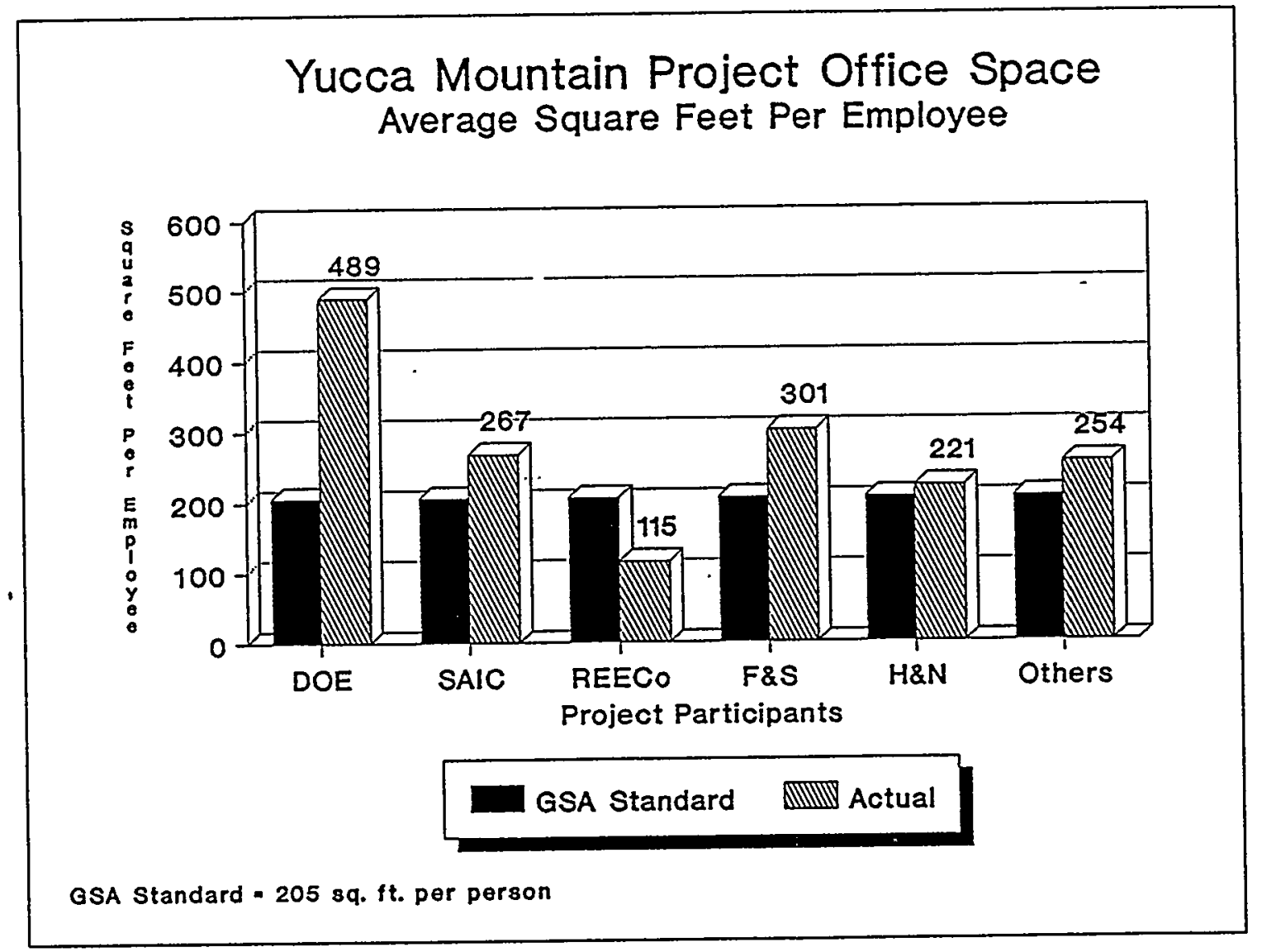

Project office officials were unable to justify the additional 45,000 square feet of leased office space. These officials advised that, due to budget restrictions, project participants had recently reduced staffing by 150 positions. 
Project officials anticipated that the overall staff size would remain at approximately 700 Department and contractor employees during the remainder of FY 1990 and in FY 1991.

As a result of SAIC leasing the additional 45,000 square feet of space, SAIC will incur unreasonable costs of about $\$ 600,000$ during the first year beginning March 4, 1990. In addition, if SAIC continues to maintain the excess space after this initial year, SAIC would incur additional unreasonable costs of about $\$ 1.2$ million during the remaining 24 months of the lease.

\section{SAIC Lease Extension}

On January 3, 1990, SAIC exercised an option for a 3-year lease extension which did not meet the liability limiting requirements of Department order 4300.1A. The lease extension, beginning March 4, 1990, included a 1-year payment guarantee at a cost of $\$ 2.5$ million. The omission of the clause limiting the Department's liability makes the Department monetarily responsible for the full lease during the first year. Therefore, the Project office could be liable for any part of the $\$ 2.5$ million lease cost remaining if the Yucca Mountain Project was reduced or terminated during the first 12 months.

\section{Applicability of Department Policy}

To prevent such unfavorable lease arrangements, Department order $4300.1 \mathrm{~A}$ required prior approval of the Director of Administration before signing any lease for more than 1 year at a cost exceeding $\$ 50,000$. However, Project Office officials stated that they did not believe the requirements of Department Order 4300.1A applied when a contractor, such as SAIC, signed the lease. Furthermore, because SAIC signed the lease, Project officials believed that the Department incurred no additional risk. Also, because they did not believe that the Department policy was applicable to SAIC, Project officials did not review space allotments for compliance with the GSA standard.

We believe the Project officials were mistaken about the applicability of Departmental policy. Project officials should have followed Departmental policy because: (1) the Request for Proposal required that the selected contractor follow Department Order 4300.1A if office space was leased solely for the project; (2) SAIC $^{\prime}$ s contract required that space be leased solely for the project; and (3) the Government and its other contractors occupied a substantial portion of the leased space, in this case 45 percent.

In addition, we believe that the Department could be held liable if the project were terminated because: (1) the Project office directed SAIC to obtain the lease and approved the extension; (2) the Project office approved project participants 
requests for space; (3) the SAIC . contract was cost reimbursable; and (4) the Project Office was directly billed by SAIC for space occupied by the Project office and its other contractors.

\section{RECOMMENDATIONS}

We recommend that the Director, office of Civilian Radioactive Waste Management, advise:

1. The Manager, Yucca Mountain Project office, that Departmental space leasing policies apply to the SAIC contract and direct the Manager to:

a. Establish procedures for monitoring contractor leased office space to ensure compliance with Department policy;

b. Require SAIC to evaluate Project space requirements and reduce space where economical and in the best interest of the Department; and

c. Determine what alternative approaches might be available to limit the Department's lease liability should the project be terminated.

2. The Contracting officer that any costs associated with lease expenses for space which exceeds the GSA standard should be treated as unreasonable under the terms of the contract.

\section{MANAGEMENT REACTION}

OCRWM officials agreed with our findings and recommendations. The Project Manager has directed SAIC to make quarterly reports on participant space requirements based on staffing levels. OCRWM assured us that there were no plans at this time to terminate the Project. Although the exact number of employees was uncertain, OCRWM advised that consolidated space for the Project participants would continue to be necessary. Project officials will evaluate space requirements in November 1990 and reduce unnecessary space if it is in the best interest of the Department.

However, OCRWM officials advised us that reducing space to GSA standards would require reconfiguration. SAIC estimated that to release the excess space and reconfigure the remaining space into individual workstations could cost as much as $\$ 2.4$ million. OCRWM officials believed that any savings from releasing excess space may be negated by reconfiguration costs. 


\section{AUDITOR COMMENTS}

The actions taken by OCRWM and Project officials are responsive to our recommendations and should provide reasonable assurance that space use will be within accepted standards.

We agree that reconfiguration may be necessary to reduce space to the GSA standard and that the cost of reconfiguration could negate the savings associated with releasing the excess space. However, we did not have an opportunity to review SAIC's proposed reconfiguration plan since it was presented for the first time after the audit field work had been completed. Therefore, we are not in a position to evaluate whether the reconfiguration plan is realistic or whether it would be as costly as claimed. Even if the reconfiguration plan and the associated costs are valid, we believe there would be savings of at least $\$ 1.2$ million over and above such costs assuming available lease options (currently 6 years) are exercised.

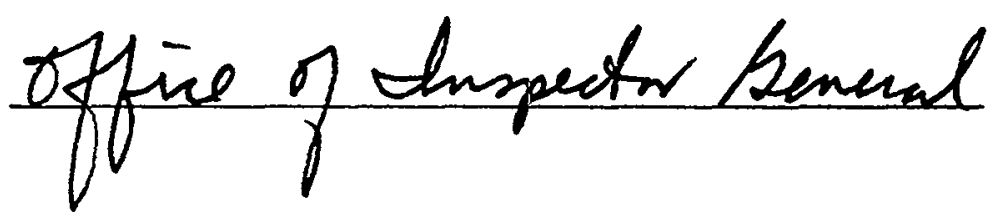

